\title{
Bacterial cellulose production by Gluconacetobacter xylinus by employing alternative culture media
}

\author{
Angela Faustino Jozala • Renata Aparecida Nedel Pértile • Carolina Alves dos Santos • \\ Valéria de Carvalho Santos-Ebinuma • Marcelo Martins Seckler • Francisco Miguel Gama • \\ Adalberto Pessoa Jr.
}

Received: 12 September 2014 / Revised: 10 November 2014 / Accepted: 12 November 2014 / Published online: 4 December 2014

(C) Springer-Verlag Berlin Heidelberg 2014

\begin{abstract}
Bacterial cellulose (BC) is used in different fields as a biological material due to its unique properties. Despite there being many BC applications, there still remain many problems associated with bioprocess technology, such as increasing productivity and decreasing production cost. New technologies that use waste from the food industry as raw materials for culture media promote economic advantages because they reduce environmental pollution and stimulate new research for science sustainability. For this reason, BC production requires optimized conditions to increase its application. The main objective of this study was to evaluate BC production by Gluconacetobacter xylinus using industry waste, namely, rotten fruits and milk whey, as culture media. Furthermore, the structure of BC produced at different conditions was also determined. The culture media employed in this study were
\end{abstract}

A. F. Jozala $(\bowtie) \cdot$ A. Pessoa Jr.

Department of Biochemical and Pharmaceutical Technology, FCF Universidade de São Paulo (USP), São Paulo, SP, Brazil

e-mail: angelafj@usp.br

\section{A. F. Jozala}

Department of Pharmacy, Universidade de Sorocaba (UNISO),

Sorocaba, SP, Brazil

\section{R. A. N. Pértile}

Department of Chemical Engineering, Universidade Federal de Santa Catarina (UFSC), Florianópolis, Santa Catarina, Brazil

C. A. dos Santos • M. M. Seckler

Department of Chemical Engineering, Universidade de São Paulo (USP), São Paulo, SP, Brazil

V. de Carvalho Santos-Ebinuma

Department of Bioprocess and Biotechnology, School of Pharmaceutical Sciences, Universidade Estadual Paulista (UNESP), Araraquara, SP, Brazil

F. M. Gama

Department of Biologic Engineering, Universidade do Minho

(UMINHO), Gualtar, Braga, Portugal composed of rotten fruit collected from the disposal of free markets, milk whey from a local industrial disposal, and their combination, and Hestrin and Schramm media was used as standard culture media. Although all culture media studied produced $\mathrm{BC}$, the highest $\mathrm{BC}$ yield $-60 \mathrm{mg} / \mathrm{mL}$ - was achieved with the rotten fruit culture. Thus, the results showed that rotten fruit can be used for $\mathrm{BC}$ production. This culture media can be considered as a profitable alternative to generate high-value products. In addition, it combines environmental concern with sustainable processes that can promote also the reduction of production cost.

Keywords Bacterial cellulose $\cdot$ Rotten fruit $\cdot$ G. xylinus $\cdot$ Milk whey $\cdot$ Bioprocess

\section{Introduction}

At present, several studies are being conducted worldwide to produce cellulose by using processes that reduce both environmental impact and production cost. Cellulose, which can be produced by several sources, is one of the most abundant macromolecule on Earth (Klemm et al. 2001; Sheykhnazari et al. 2011). Although its production is mostly by vascular plants, an alternative route that not only replaces but also reduces the demand from plants is the production of cellulose from another resource such as a bacterial system (Sheykhnazari et al. 2011; Brown 2003; Castro et al. 2011; Lin et al. 2013).

Bacterial cellulose (BC) is an extracellular polysaccharide secreted mainly by Gluconacetobacter xylinus, a rod-shaped, strictly aerobic gram-negative bacterium (Moosavi-Nasab and Yousefi 2011; Li et al. 2012). This microorganism produces a pellicle of BC that has a nanofibrillar structure, with a denser surface on one side and a gelatinous layer on the other side 
(Klemm et al. 2001; Kurosumi et al. 2009; Cai and Kim 2010; Nakagaito et al. 2010).

$\mathrm{BC}$ does not have lignin and hemicellulose like cellulose from plants, making it a highly pure source of cellulose (Mohite and Patil 2014). BC is also distinguished from its plant equivalent by a high crystallinity index (above $60 \%$ ) and different degree of polymerization (DP), usually between 2000 and 6000 (Mohite and Patil 2014). Due to its unique properties, $\mathrm{BC}$ has been employed as a new biological material in the food industry, as edible packing medical, as wounddressing materials, artificial skin, vascular grafts, scaffolds for tissue engineering, artificial blood vessels, medical pads and dental implants (SHAH et al. 2013), and industrial products, as sponges to collect leaking oil and materials for absorbing toxins, Optoelectronics materials (liquid crystal displays) (Donini et al. 2010).

The main problems associated with the bioprocess technology are productivity, ease of industrial application, and production cost (Koutinas et al. 2012). Despite all applications, the elevated $\mathrm{BC}$ production costs associated with the use of expensive culture media have encouraged studies to optimize the bioprocess aiming to achieve high yields capable of meeting the worldwide demand for cellulose (Donini et al. 2010).

As the substrates, especially the carbon source, can determine the costs of microbial fermentation processes, and particularly for BC production the culture media can be responsible for up to $65 \%$ of the total process cost, several studies have been devoted to find new low-cost carbon sources, as glycerol remaining from biodiesel production and grape bagasse, a residue of wine production, coffee cherry husk extract, and corn steep liquor (Moosavi-Nasab and Yousefi 2011; Vazquez et al. 2013; Castro et al. 2013; Rani et al. 2011; Carreira et al. 2011).

Since acetic acid bacterium such as G. xylinum can assimilate several sugars (Verschuren et al. 2000; Ishihara et al. 2002; Bae and Shoda 2004), different sources have been studied by other authors among them: coconut water (Kongruang 2008); pineapple and sugar cane juices (Castro et al. 2011); syrup of a typical fruit of Iran (Moosavi-Nasab and Yousefi 2011); and agroindustry such as grape skins, whey, raw glycerol, and sulfite pulp (Carreira et al. 2011). Recently, Vazquez et al. (2013) modified carbon sources in the Hestrin and Schramm (HS) culture medium by replacing commercial glucose or glycerol with grape bagasse from wine production and remaining glycerol from biodiesel production. Kurosumi et al. (2009) employed different fruit juices such as orange, pineapple, apple, Japanese pear, and grape in the $\mathrm{BC}$ production. The present study employed a mix of fruit rotten as an alternative source to reduce the cost of culture media for producing $\mathrm{BC}$.

When fruits cannot be marketed due to poor quality caused by bad weather or other natural disasters, it leads to rotten fruit (Kurosumi et al. 2009). In addition, disposal from dairy industries has received special attention due to its polluting effect on the environment (Arauz et al. 2009). It is not often recognized that milk can have a significant polluting effect on rivers or streams. It can be as much as 400 times more polluting than untreated domestic sewage. Naturally occurring bacteria break down milk entering a watercourse, consuming the oxygen in the water more quickly than it can be replaced. As a result of decay of oxygen levels, fish and other creatures can suffocate.

Such wastes are rich in sugars, which can be easily assimilated by microorganisms. This makes them suitable for the industrial production of bioproducts by microorganisms (Rosales et al. 2005).

The utilization of the rotten fruits and pomace fruits was evaluated and efficacy system because for fruit processing industries are considerable by-products. They explained that prices for these by-products are lower because they usually have few alternative uses (Kennedy and Krouse 1999). For these reason, applying these materials as culture medium, even treated to reduce fiber and high molecular weight polysaccharides, could be a good alternative for research. The development of culture media to fermentative process is of paramount importance since its composition can impact in the productivity, purification process, and product quality (Kennedy and Krouse 1999).

In the production process, the value of the culture medium represents $30 \%$ of the total cost of production (Rivas et al. 2004). Therefore, development of a process by using culture media from rotten fruits and dairy industry waste would be an important achievement, since it could reduce the cost process and support large-scale development.

Thus, the main objectives of this study were to evaluate $\mathrm{BC}$ production by G. xylinus by using rotten fruits and milk whey as culture media without supplementation and to verify the effects of this different culture media on $\mathrm{BC}$ structure.

\section{Material and methods}

\section{Culture media}

The $\mathrm{BC}$ was produced using the following culture media: Hestrin and Schramm (HS) containing glucose $20 \mathrm{~g} / \mathrm{L}$, peptone $5 \mathrm{~g} / \mathrm{L}$, yeast extract $5 \mathrm{~g} / \mathrm{L}$, sodium phosphate anhydrous $2.7 \mathrm{~g} / \mathrm{L}$, and citric acid monohydrate $1.15 \mathrm{~g} / \mathrm{L}$; rotten fruits composed of plums, green grapes, pineapples, and apples, which were collected from the disposal of free markets; milk whey from a local industrial disposal; and a mixture of rotten fruits and milk whey. The amount of carbon and nitrogen in each medium was determined by elemental analysis at the Central Analytical of Chemistry Institute, São Paulo University (São Paulo, Brazil). Through the mass of carbon and 
nitrogen in each medium, it was possible to calculate the carbon/nitrogen $(\mathrm{C} / \mathrm{N})$ rate, according to Eq. 1:

$C: N=\frac{\text { carbonmass }(g)}{\text { nitrogen mass }(g)}$

Table 1 presents all the culture media tested and their carbon/nitrogen $(\mathrm{C} / \mathrm{N})$ ratio. To obtain the culture media composed of rotten fruits, $250 \mathrm{~g}$ of fruits was processed in a blender with $400-\mathrm{mL}$ deionized water. Next, the juice was filtered and centrifuged at $4000 \mathrm{~g}$ for $20 \mathrm{~min}$. The supernatant was collected and used as culture media. In this culture media, milk whey and HS were sterilized at $121{ }^{\circ} \mathrm{C}$ for $30 \mathrm{~min}$ and then stored at $4{ }^{\circ} \mathrm{C}$. All media had the $\mathrm{pH}$ adjusted to 6.0 .

\section{$\mathrm{BC}$ production}

A preculture of G. xylinus ATCC 53582 was prepared using $100 \mathrm{~mL}$ of the HS broth $\left(\mathrm{M}_{0}\right)$ medium at $30^{\circ} \mathrm{C}$ for $48 \mathrm{~h}$ under 150-rpm stirring. After this, $10^{6} \mathrm{CFU} \mathrm{mL}^{-1}$ was taken from each culture medium. For BC membrane production, 24-well plates were used as the template. Each well was filled with $1 \mathrm{~mL}$ of the inoculated culture medium. The plates were kept at $30{ }^{\circ} \mathrm{C}$ in a static culture for $0,24,48,72$, and $96 \mathrm{~h}$. Analytical methods such as (i) bacterial growth, (ii) cellulose production, (iii) protein and sugar consumption, and (iv) $\mathrm{pH}$ were analyzed at each time point.

\section{Analytical methods}

The number of viable cells was determined by counting colonies formed on the HS agar surface at $30{ }^{\circ} \mathrm{C} \pm 0.5^{\circ} \mathrm{C}$ at $48 \mathrm{~h}$ adapted from methodology (Kouda et al. 1997; Naritomi et al. 1998). The culture medium was centrifuged at $10,000 \mathrm{~g}$ for $10 \mathrm{~min}$ to separate cellulose from the supernatant. The supernatant was collected, and the residual protein levels were determined according to the bicinchoninic acid (BCA) protein assay reagent by using bovine serum albumin as the standard, and sugar levels were determined using a GOD-PAD glucose kit (Laborlab, Brazil), in which the reagent is ready to be used

Table 1 Culture media percentages and carbon/nitrogen ratio $(\mathrm{C} / \mathrm{N})$ for bacterial cellulose $(\mathrm{BC})$ production

\begin{tabular}{lcccc}
\hline Culture media & Milk whey (\%) & Rotten fruit (\%) & HS (\%) & C/N \\
\hline $\mathrm{M}_{0}$ & - & - & 80 & 6.9 \\
$\mathrm{M}_{1}$ & 80 & - & - & 17.7 \\
$\mathrm{M}_{2}$ & - & 80 & - & 57.6 \\
$\mathrm{M}_{3}$ & 30 & 60 & - & 35.6 \\
$\mathrm{M}_{4}$ & 50 & 40 & - & 24.2 \\
$\mathrm{M}_{5}$ & 30 & 50 & - & 27.5 \\
\hline
\end{tabular}

Preculture of G. xylinus with $10^{6} \mathrm{CFU} / \mathrm{mL}$ and initial $\mathrm{pH} 6.0$ and employs enzymatic method for large analytical specificity. The color reaction was measured by UV spectroscopy, using a Molecular Devices Spectramax 384 Plus | UV-Vis Microplate Reader at $\lambda=505 \mathrm{~nm}$.

The produced $\mathrm{BC}$ was collected, rinsed in distilled water, and immersed in $\mathrm{NaOH} 1 \mathrm{~N}$ at $60{ }^{\circ} \mathrm{C}$ for 90 min to remove attached cells. Later, $\mathrm{BC}$ was washed in distilled water and dried at $50^{\circ} \mathrm{C}$ for $24 \mathrm{~h}$ to evaluate the $\mathrm{BC}$ yield concentration in $\mathrm{mg} \mathrm{mL}^{-1}$ (mass $(\mathrm{mg}$ ) of BC/volume (mL) of culture medium) (Moosavi-Nasab and Yousefi 2011; Hong et al. 2006).

\section{Kinetic parameters}

The $\mathrm{BC}$ productivity $\left(\mathrm{P}_{\mathrm{BC}}\right)$ and $\mathrm{BC}$ yield coefficient $\left(\mathrm{Y}_{\mathrm{P} / \mathrm{S}}\right)$, expressed in $\mathrm{mg} / \mathrm{mL} \mathrm{h}$ and $\mathrm{g}$ product $/ \mathrm{g}$ substrate, respectively, were defined as follows:

$P_{B C}=C_{B C} / t$

$Y_{P / S}=(d S / d T) /\left(d P_{B C} / d t\right)$

where $C_{B C}$ is the maximum BC concentration $(\mathrm{mg} / \mathrm{mL})$ at time $t$.

$\mathrm{BC}$ production was measured at the end of each period and corresponded to $(\mathrm{mg} / \mathrm{mL})$ the dry weight of cellulose per mililiter of culture media, as described by Moosavi-Nasab and Yousefi (2011).

\section{Characterization of $\mathrm{BC}$ membranes}

All samples were characterized in terms of surface morphology and crystallinity. BC membranes were frozen at $-70{ }^{\circ} \mathrm{C}$ for $24 \mathrm{~h}$. The samples were freeze-dried (L101 Liotop ${ }^{\mathrm{TM}}$ ) for 3 days. Following, the samples were cross-sectioned, sputtercoated with gold, and analyzed by scanning electron microscopy (SEM).

The X-ray diffraction (XRD) is a rapid analytical technique primarily used for phase identification of a crystalline material and can provide information on unit cell dimensions (Adesakin et al. 2011). The patterns of all BC membranes were determined using a PANalytical X'Pert PRO MPD diffractometer with an anode material (copper). The generator settings were (operating current and voltage) $40 \mathrm{~mA}, 45 \mathrm{kV}$; scan speed $59.69 \mathrm{~s} ; \mathrm{K}$-alpha1 $[\AA]$ 1,54060; K-alpha2 $[\AA]$ 1,54443; step size [ ${ }^{\circ} 2 \mathrm{Th}$.] 0,0170; scan type was continuos; in a range $0-60$ postsynaptic density (PSD) length [ ${ }^{\circ} 2 \mathrm{Th}$.] 2,12 ; divergence silt size $\left[{ }^{\circ}\right] 0,4785$. The diffraction profile was processed by computer-aided fitting analysis and transformed to basic crystallographic features: $d$-spacings of equatorial lattice planes. The results were attained by computer- 
aided fitting analysis. The assays were performed at Instituto de Pesquisas Tecnológicas SP/Brazil (IPT).

\section{Statistical analysis}

All the analyses were performed in triplicate and the results expressed as mean values with the error bars calculated representing a confidence limit of $95 \%$ for the measurements. Moreover, the generated data were treated by Tukey test to identify whether changes in the parameters assessed were significant at $95 \%$ significance.

\section{Results}

\section{$\mathrm{BC}$ production}

To verify the effect of culture media on G. xylinus growth and $\mathrm{BC}$ production, the bacteria preculture was made in a standard culture medium $\mathrm{M}_{0}$ (HS broth) containing $10^{6} \mathrm{CFU} \mathrm{mL}$ cells. This procedure was performed to ensure the same number of cells in each well so that $\mathrm{BC}$ membranes could undergo identical development.

Figure 1 shows that the experiments performed with culture media containing rotten fruit had a higher $\mathrm{BC}$ production. Among these results, after $96 \mathrm{~h}$ of bioprocess, the $\mathrm{BC}$ production was $\mathrm{M}_{2}, 60.0 ; \mathrm{M}_{5}, 52.8 ; \mathrm{M}_{4}, 48.1 ; \mathrm{M}_{3}, 40.0 \mathrm{mg} / \mathrm{mL}$. The time which promoted the highest $\mathrm{BC}$ production varied according the culture media. To the standard media $\left(\mathrm{M}_{0}\right)$, the highest production was achieved at $48 \mathrm{~h}$ of process while to culture media, $\mathrm{M}_{4}$ and $\mathrm{M}_{5} 96 \mathrm{~h}$ promoted the highest production. Regarding the culture media $\mathrm{M}_{2}$, the error bars indicate that there was no statistical difference among the $\mathrm{BC}$

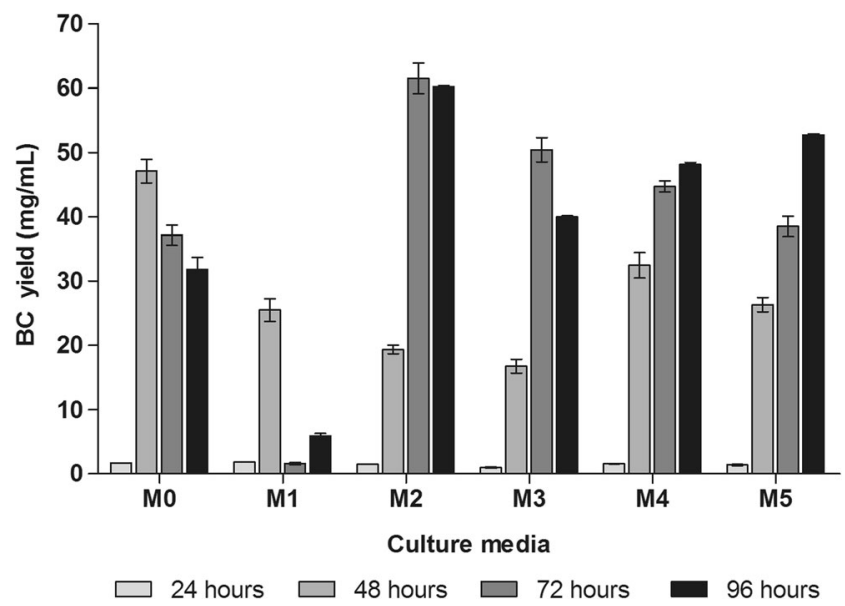

Fig. 1 Bacterial cellulose $(B C)$ yield $(\mathrm{mg} / \mathrm{mL})$ in different culture media in static culture for $24,48,72$, and $96 \mathrm{~h}$. All the experiments were performed in triplicate. The error bars represent a confidence limit of $95 \%$ for the measurements. $M_{0}$ HS broth; $M_{1}$ milk whey; $M_{2}$ rotten fruit; $M_{3}, M_{4}$, and $M_{5}$ milk whey/rotten fruit production at 72 and $96 \mathrm{~h}$. The quickest production obtained with culture media $\mathrm{M}_{0}$ can be a result of the easier assimilation of nutrients present at this media as compared to the ones in the complex media.

Considering the time of $96 \mathrm{~h}$, the use of rotten fruit as culture media promoted an enhance in the $\mathrm{BC}$ yield, independently of its concentration. Comparing the results obtained at media $\mathrm{M}_{0}$ with the others, it achieved an increase in the BC yield around $89,25,51$, and $66 \%$ for media $\mathrm{M}_{2}, \mathrm{M}_{3}, \mathrm{M}_{4}$, and $\mathrm{M}_{5}$, respectively. Tukey test at $5 \%$ probability was applied to $\mathrm{BC}$ yield results, and it was observed that different statistics among all the results are achieved. The " $p$ " value obtained to these results was 0.001 .

The $\mathrm{C} / \mathrm{N}$ ratio (Table 1) was different for each media studied, which can have contributed for the results achieved. The media $\mathrm{M}_{2}$ had the higher $\mathrm{C} / \mathrm{N}$ ratio, namely, 57.6; this value was 1.6, 2, 2.4, 3.4, and 8 times higher than that in $\mathrm{M}_{3}$, $\mathrm{M}_{5}, \mathrm{M}_{4}, \mathrm{M}_{1}$, and $\mathrm{M}_{0}$, respectively. So, the results obtained can be related not only with how easy is the carbon assimilation by the microorganism but also with its amount in the culture media. Although the $\mathrm{C} / \mathrm{N}$ ratio in $\mathrm{M}_{1}$ was higher than that in $\mathrm{M}_{0}$, the first one was composed by milk whey, in which the main carbon source is lactose, and the microorganism had to develop a different metabolic route promoting a lower BC yield.

To the other hand, culture media containing rotten fruits blended with milk whey contain sufficient nutrients that contribute to the bacterial cell growth and $\mathrm{BC}$ production. The results of cell growth and $\mathrm{pH}$ were determined at $96 \mathrm{~h}$ of bioprocess, which was considered the final time of fermentation. The cell growth was similar to media $\mathrm{M}_{3}, \mathrm{M}_{4}$, and $\mathrm{M}_{5}$. The lowest cell growth was achieved with media $\mathrm{M}_{2}$ while the media $\mathrm{M}_{0}$ and $\mathrm{M}_{1}$ provided intermediate results (Table 2).

Table 2 shows the amount of sugar and protein in the media used to produce cellulose before and after the fermentation process compared with $\mathrm{BC}$ yield values. At time 0 , the total protein content in the medium showed different concentrations, varying from 4 to $12 \mathrm{~g} / \mathrm{L}$. The total sugar content varied from 10 to $20 \mathrm{~g} / \mathrm{L}$. The results showed a similar pattern of protein consumption; however, the media containing rotten fruit had a higher protein concentration before and after BC production.

The $\mathrm{pH}$ was at acidic conditions in the end to all media evaluated. The $\mathrm{pH}$ values of media $\mathrm{M}_{0}, \mathrm{M}_{1}$, and $\mathrm{M}_{3}$ were 3.2, 3.4, and 3.9, respectively, and those of media $\mathrm{M}_{2}, \mathrm{M}_{4}$, and $\mathrm{M}_{5}$ were 4.5, 5.4, and 4.4, respectively. However, higher production was achieved at $\mathrm{pH}$ values around $4-5$, as demonstrated in Table 2.

Several previous studies showed that another relevant factor that influences $\mathrm{BC}$ production is the volume of the culture medium in a determined type of flask culture. It is important to consider that this parameter is essential for the membrane size and yield of $\mathrm{BC}$ production. 
Table 2 Sugar and protein concentrations in each culture medium to produce bacterial cellulose (BC) before and after the fermentation process, along with the BC yield values obtained at the final process $(96 \mathrm{~h})$

\begin{tabular}{|c|c|c|c|c|c|c|c|c|c|c|c|c|}
\hline Culture media & $\mathrm{M}_{0}$ & & $\mathrm{M}_{1}$ & & $\mathrm{M}_{2}$ & & $\mathrm{M}_{3}$ & & $\mathrm{M}_{4}$ & & $\mathrm{M}_{5}$ & \\
\hline Time (h) & 0 & 96 & 0 & 96 & 0 & 96 & 0 & 96 & 0 & 96 & 0 & 96 \\
\hline Proteins (mg/mL) & 4.1 & 0.8 & 4.0 & 1.9 & 10.0 & 4.1 & 10.1 & 2.1 & 8.1 & 1.3 & 9.1 & 2.2 \\
\hline $\mathrm{pH}$ & 4.6 & 3.2 & 4.9 & 5.4 & 3.8 & 3.43 & 4.1 & 3.8 & 4.2 & 4.5 & 4.2 & 4.4 \\
\hline $\log C F U / m L$ & 5.0 & 6.7 & 5.0 & 6.4 & 5.0 & 7.3 & 5.0 & 7.2 & 5.0 & 6.8 & 5.0 & 7.0 \\
\hline Sugar (mg/mL) & 20.0 & 2.4 & 10.0 & 4.1 & 16.3 & 2.9 & 17.3 & 4.9 & 18.2 & 5.8 & 17.7 & 4.2 \\
\hline $\mathrm{BC}$ yield $(\mathrm{mg} / \mathrm{mL})$ & - & 31.8 & - & 5.9 & - & 60.2 & - & 40 & - & 48.1 & - & 52.8 \\
\hline
\end{tabular}

$M_{0}$ HS broth, $M_{1}$ milk whey, $M_{2}$ rotten fruit, $M_{3} M_{4}$ and $M_{5}$ milk whey/rotten fruit

Ruka et al. (2012) observed that the surface area/volume ratio of cellulose was dependent on the culture medium volume; for example, $80 \mathrm{~mL}$ of culture medium for $\mathrm{BC}$ production would give a surface area/volume ratio of approximately $0.71 \mathrm{~cm}^{-1}$ and would most likely provide a suitable depth to microorganism development and to produce high amounts of cellulose. Ratios between 0.57 and $0.71 \mathrm{~cm}^{-1}$ would provide depth of 1.75 and $1.4 \mathrm{~cm}$, respectively, which would most likely give the most cost-effective quantities of media to obtain maximum $\mathrm{BC}$ yields. As in this work, the relation between medium consumption/volume was the same for all culture media; this parameter had any influence in the results obtained. The final membranes were approximately $2 \mathrm{~mm}$ thin.

However, the $\mathrm{BC}$ membrane size is also dependent on the culture media used in $\mathrm{BC}$ production. Our results showed that the culture media containing milk whey produced a pellicle that was thinner than that produced by other culture media even if they had started with the same media volume $(1 \mathrm{~mL})$. The size of $\mathrm{BC}$ is a relevant factor in its production because it is directly associated with the application area.

$\mathrm{BC}$ produced after $72 \mathrm{~h}$ of fermentation from culture media containing milk whey $\left(\mathrm{M}_{1}\right)$ was susceptible to treatment with $\mathrm{NaOH}$, a standard process used to purify $\mathrm{BC}$; therefore, yield calculation, SEM imaging, and DRX analyses could not be continued. However, to show that in a culture media containing milk whey it was possible to produce $\mathrm{BC}$, the sample obtained at $48 \mathrm{~h}$ was characterized (data not shown) proving that in this culture media, there was $\mathrm{BC}$ production.

\section{Kinetic study}

Kinetic parameters are essential not only to estimate the cost of a bioprocess but also to develop control strategies (BaptistaNeto et al. 2000). In this way, some kinetic parameters, specifically $\mathrm{BC}$ productivity $\left(\mathrm{P}_{\mathrm{BC}}\right)$ and yield of substrate on product $\left(\mathrm{Y}_{\mathrm{P} / \mathrm{S}}\right)$, were investigated, and the results are shown in Fig. 2.

The culture media $M_{2}$ showed the highest value for both parameters, namely, 4.45 for yield of substrate on product and 0.63 for productivity. Although the culture media containing only rotten fruit $\left(\mathrm{M}_{2}\right)$ promoted the highest kinetic parameters when combined rotten fruit and milk whey, the conditions carried with a lower percentage of rotten fruit showed better results; as example with the culture media $\mathrm{M}_{3}$ (60\% rotten fruit), a productivity of $0.42\left(\mathrm{~h}^{-1}\right)$ was achieved while that with culture media $\mathrm{M}_{5}$ (50\% rotten fruit), the value of this parameter was $0.55\left(\mathrm{~h}^{-1}\right)$. So, rotten fruit is a suitable media to obtain $\mathrm{BC}$, and its combination with milk whey can prejudice the process.

The productivity achieved in the medium $\mathrm{M}_{2}$ was approximately $\left(0.63 \mathrm{~h}^{-1}\right) 10$-fold higher than that obtained in the medium $\mathrm{M}_{1}\left(0.06 \mathrm{~h}^{-1}\right)$, which contained only milk. The type of sugar present in each medium can be the main reason for the results achieved. Since culture media $\mathrm{M}_{2}$ showed the best results with respect to kinetic parameters, this media can be used as an alternative to produce $\mathrm{BC}$.

\section{$\mathrm{BC}$ characterization}

Figure 3 presents the difference in surface morphology by comparing the culture media $\mathrm{M}_{3}$ and $\mathrm{M}_{4}$ with other $\mathrm{BC}$

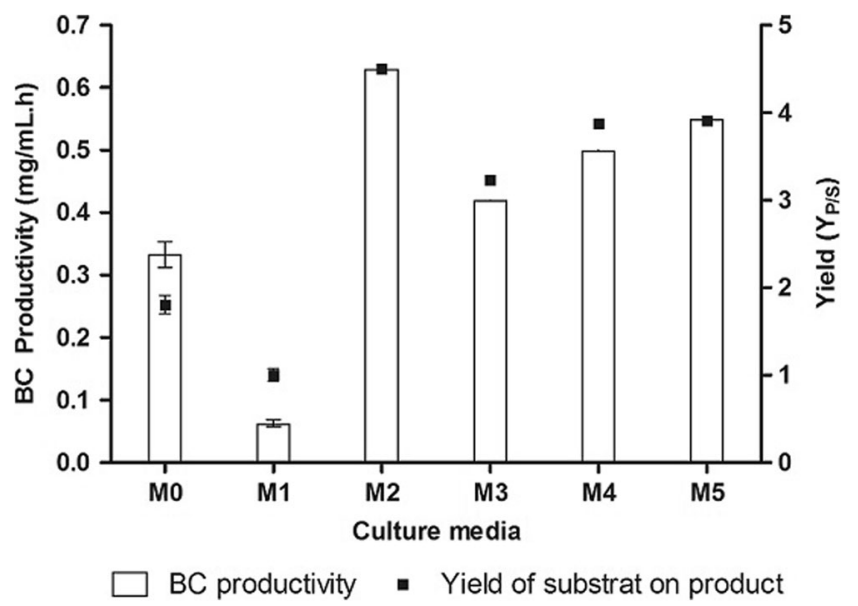

Fig. 2 Bacterial cellulose (BC) productivity $\left(\mathrm{h}^{-1}\right)$ and yield of substrate in product $\left(\mathrm{Y}_{\mathrm{P} / \mathrm{S}}\right)$ at $96 \mathrm{~h}$ of fermentation. Gray bars represent the $\mathrm{BC}$ productivity and black line represents the yield. The error bars represent a confidence limit of $95 \%$ for the measurements. $M_{0}$ HS broth; $M_{1}$ milk whey; $M_{2}$ rotten fruit; $M_{3}, M_{4}$, and $M_{5}$ milk whey/rotten fruit 
Fig. 3 SEM images of the top view of the bacterial cellulose (BC) produced in a BC standard $\left(M_{0} \mathrm{HS}\right), \mathbf{b} \mathrm{BC}$ from milk whey/rotten fruit $\left(M_{3}\right), \mathbf{c} \mathrm{BC}$ from milk whey/rotten fruit $\left(M_{4}\right), \mathbf{d}$ BC from milk whey/rotten fruit $\left(M_{5}\right)$, and $\mathbf{e} \mathrm{BC}$ from rotten fruit $\left(M_{2}\right)$
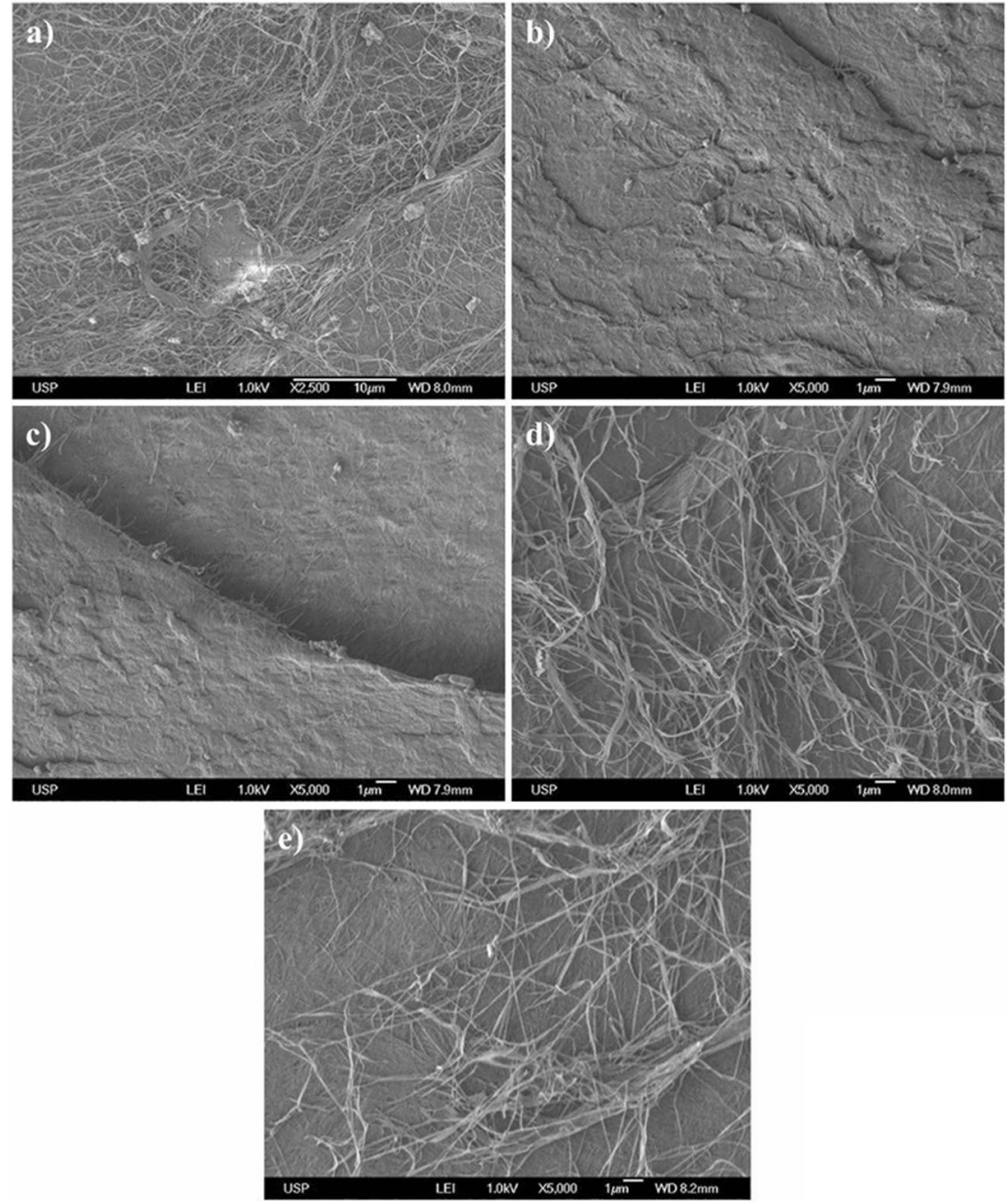

membranes after $96 \mathrm{~h}$. The SEM images of the BC membranes exhibited their top view (denser side). The loose fibrillar structure of the standard $\mathrm{M}_{0}, \mathrm{M}_{5}$, and $\mathrm{M}_{2}$ contrasts with the compact and diminished surface porosity of the $\mathrm{M}_{3}$ and $\mathrm{M}_{4}$ cellulose. This compact cellulose network structure is composed of a random assembly of fibrils (Sheykhnazari et al. 2011). The structure of the $B C$ produced in $\mathrm{M}_{2}$, which contained only rotten fruit, was similar to the standard culture media $\mathrm{M}_{0}$. These differences can influence the final application of cellulose where more porous or compact structures are necessary to create a certain device or environment (Fig. 3).

$\mathrm{BC}$ crystallinity was also investigated using XRD technique, and the X-ray patterns of $\mathrm{BC}$ are exhibited in Fig. 4. The obtained X-ray patterns show cellulose with the same chemical structure but with different crystallinity degrees (Table 3 ). Using the culture media $\mathrm{M}_{0}$ as the standard sample, 2 main crystalline regions can be observed in the 14 and 22 positions, as previously reported by Yan et al. (2008), Phisalaphong and Jatupaiboon (2008), and Saibuatong and Phisalaphong (2010) who observed crystallinity areas varying from 64.6 to $100 \%$, respectively. The same peaks were obtained for other samples, differing only in the crystalline percentage. However, for $\mathrm{BC}$ produced in $\mathrm{M}_{2}$ medium containing rotten fruit, the peak showed a superior crystalline area compared with the standard one (Table 3).

According to the results reported, this bacterial strain is capable of producing quality cellulose at high yields with rotten fruit as the culture medium, with similar characteristics to those reported for BC produced in the standard medium, thus providing favorable conditions for recycling waste.

\section{Discussion}

The highest $\mathrm{BC}$ yield, determined in $\mathrm{mg} \mathrm{mL}^{-1}$ (mass [mg] of $\mathrm{BC} /$ volume $[\mathrm{mL}]$ of culture medium), achieved in this study, was 10-fold higher than the results obtained by Kurosumi et al. (2009). The cited authors studied BC production in different culture media containing fruit juice and showed a higher cellulose yield $(6 \mathrm{mg} / \mathrm{mL})$ from culture media containing orange juice after $96 \mathrm{~h}$ of cultivation. Zeng et al. (2011) 
Fig. 4 Bacterial cellulose (BC) cristallinity by $\mathrm{X}$-ray difraction and the X-ray patterns. $\mathrm{M}_{0}$ is standard sample; $\mathrm{M}_{2}$ rotten fruit; $\mathrm{M}_{4}$ milk whey/rotten fruit; $\mathrm{M}_{5}$ milk whey/rotten fruit; bold red arrows show the right positions of peaks to $\mathrm{BC}$
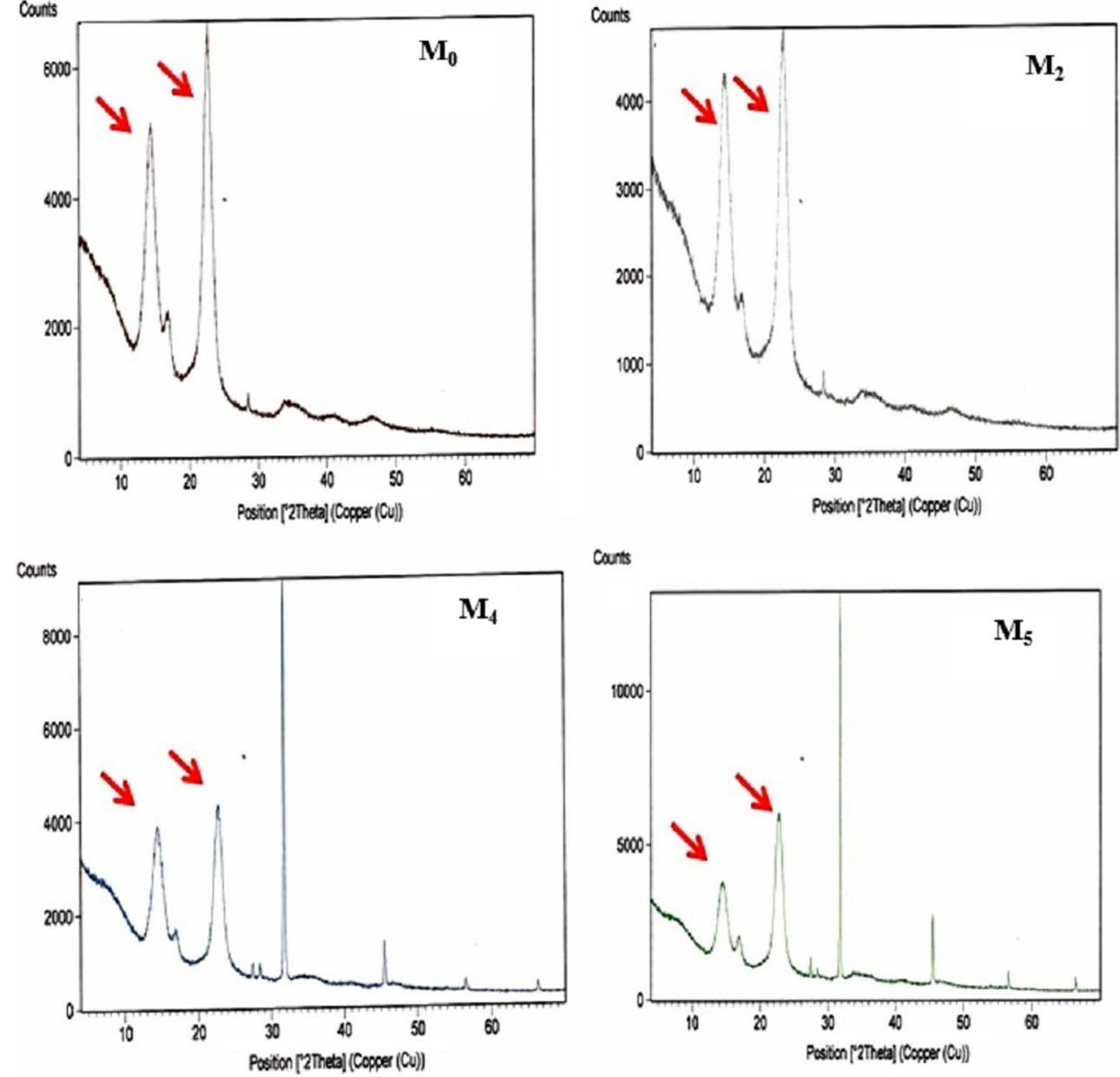

demonstrated that $\mathrm{BC}$ can be produced after 21 days in a flask culture at a $1.51-\mathrm{mg} / \mathrm{mL}$ rate with maple syrup residues as the carbon source. Wu and Liu (2012) studied BC production in HS broth supplemented with thin stillage (TS) and observed that $100 \%$ TS supplement enhanced the production to a concentration of $10.38 \mathrm{mg} / \mathrm{mL}$ after 7 days of cultivation.

Table 3 Positions, d-spacing, and cristallinity by X-ray difraction and the X-ray patterns of bacterial cellulose

\begin{tabular}{lllc}
\hline Samples & Pos. $\left({ }^{\mathrm{o}} 2 \mathrm{Th}.\right)$ & d-spacing $(\AA)$ & Cristallinity \% \\
\hline $\mathrm{M}_{0}$ & 14.96 & 5.92 & 64.66 \\
& 22.73 & 3.91 & 100 \\
$\mathrm{M}_{2}$ & 14.8 & 5.98 & 70.69 \\
& 22.69 & 3.91 & 100 \\
$\mathrm{M}_{3}$ & 14.8 & 5.98 & 15.70 \\
& 22.85 & 3.89 & 35.87 \\
$\mathrm{M}_{4}$ & 14.74 & 6.00 & 59.76 \\
& 22.83 & 3.89 & 74.52 \\
$\mathrm{M}_{5}$ & 14.69 & 6.03 & 27.23 \\
& 22.77 & 3.90 & 37.58 \\
\hline
\end{tabular}

$M_{0}$ HS broth, $M_{2}$ rotten fruit, $M_{3} M_{4}$ and $M_{5}$ milk whey/rotten fruit
Both productivity and yield of $\mathrm{BC}$ were higher in the culture media containing only rotten fruit, i.e., culture media $\mathrm{M}_{2}$. This result shows that it was possible to increase $\mathrm{BC}$ production by employing rotten fruit as the culture medium. Gomes et al. (2013) employed dry olive mill residues for the production of $\mathrm{BC}$, and the results showed an increase in the production, with lower yields in 96-h BC yield of $0.099 \mathrm{gBC} /$ $\mathrm{gS}$, yield of substrate on product. Jung et al. (2010) employed molasses and corn steep liquor to reduce the cost incurred for culture media and achieved the maximum BC yield of $2.21 \mathrm{mg} / \mathrm{mL}$, which corresponds to dry weight of cellulose per milliliter of the culture media. In our study, the best result was $60 \mathrm{mg} / \mathrm{mL}$ from $\mathrm{M}_{2}$ culture medium, which was 30 times higher than that achieved by Jung et al. (2010).

Vazquez et al. (2013) studied BC low-cost carbon sources such as glycerol from biodiesel production and grape bagasse, a residue of wine. The results showed that maximum BC production was achieved after 14 days of cultivation by employing approximately $10 \mathrm{mg} / \mathrm{mL}$ glycerol and $8 \mathrm{mg} / \mathrm{mL}$ for grape bagasse.

Some studies describe glucose, unlike other sugars, not only as an energy source but also as an ideal precursor for the assembly of structured cellulose. Consumption during 
bacterial incubation is nearly total and in quantitative agreement with the amount of BC produced (Masaoka et al. 1993; Klemm et al. 2001; Castro et al. 2011). Mikkelsen et al. (2009) studied different carbohydrate sources for $\mathrm{BC}$ production and observed that G. xylinus preferentially metabolizes monosaccharides such as fructose and glucose. In fact, milk whey contains lactose, a disaccharide, in abundance, which is unfavorable for BC production by G. xylinus cells. This explains the inferior value in sugar consumption as well as the lower yield value of $5.9 \mathrm{mg} / \mathrm{mL}$ observed in culture media containing only milk whey.

$\mathrm{BC}$ production involves several enzymes. Their regulation is an essential step for BC production. Enzyme regulation of the branched hexose monophosphate (HMP) involves the Embden-Meyerhof-Parnas (EMP) and tricarboxylic acid (TCA) pathways (Li et al. 2012). As cited before, glucose is the most commonly sugar employed for the biosynthesis of $\mathrm{BC}$, but this substrate generates several by-products such as gluconic acid, which leads to low yields for BC. Alternatively, Li et al. (2012) studied the addition of ethanol and sodium citrate to the medium, which generated fewer by-products. Thus, the use of rotten fruit, which contains fructose as the main carbon source, can both reduce the generation of byproducts and increase the yield of $\mathrm{BC}$.

According to literature (Vandamme et al. 1998; Joseph et al. 2003; Park et al. 2006), the pH of the culture medium is a critical factor for BC productivity. Panesar et al. (2012) have observed that lower $\mathrm{pH}$ and incubation time result in minimum cellulose production; however, cellulose production increases with an increase in incubation time and $\mathrm{pH}$.

In addition, Pourramezan et al. (2009) indicated that alkaline $\mathrm{pH}$ is favorable for cellulose production because of the minimum conversion of glucose into gluconic acid, which increases cellulose production. In this study, $\mathrm{pH}$ was not the limiting factor to $\mathrm{BC}$ production. The $\mathrm{pH}$ values varied from 4.5 to 5.5 and did not exert any effect on the production of BC since a production higher than found in the literature was achieved.

All the samples characterized showed BC with typical characteristics such as nanodimensional network and microfibrils. Furthermore, XRD profiles were in accordance with those presented by other authors (Mikkelsen et al. 2009; Jung et al. 2010; Carreira et al. 2011; Gomes et al. 2013).

With respect to productivity, it is important to consider the $\mathrm{C} / \mathrm{N}$ ratio in culture media because the media containing rotten fruit have higher carbon concentrations. $\mathrm{BC}$ production can be improved by varying not only the carbon concentration but also the type of sugar employed. The results of $\mathrm{BC}$ characterization showed that the membrane produced in media $\mathrm{M}_{0}$ (standard) compared to that produced in media $\mathrm{M}_{2}$ (compound of rotten fruit) had the same structural characteristics.

In summary, for the success of a fermentation process, operations involved in production and in recovery should be simple and cost-effective. It should reduce costs and time and maximize revenue, productivity, and quality of the product of interest (Thiry and Cingolani 2002). This study demonstrated an excellent way to produce $\mathrm{BC}$ by employing culture media at a low cost, which can be improved by optimizing the process. Furthermore, $\mathrm{BC}$ can be produced by employing rotten fruit media as a carbon source to achieve high yields. Indeed, for all the analyzed time points, the ideal period to obtain the BC membranes seems to be $96 \mathrm{~h}$.

Our results showed that use of rotten fruit and its combinations can be used as a substrate for the production of $\mathrm{BC}$ by G. xylinus. This culture media promotes economic advantages, reduces environmental pollution, and stimulates research on science sustainability. Furthermore, it is essential to science development alternative ways to reuse waste, which bring an ecology awareness and a significant socioeconomic impact. The cost-effectiveness of the media in terms of cellulose yield and productivity is an important factor to optimize the production. Thus, the results of this study provide a profitable alternative to generate high-value products. In addition, they present an excellent viewpoint to produce a biomaterial with different possible applications by using waste.

Acknowledgments The authors would like to acknowledge the Brazil National Council of Technological and Scientific Development (CNPq, FAPESP, and CAPES), the financial support from FAPESP 2009/148977, and Fundação para a Ciência e a Tecnologia (FCT)/Portugal through the project PTDC/EBB-EBI/112170/2009 for the financial support and scholarship. Special thanks to Talita Almeida Vicentin for technical support.

\section{References}

Adesakin AO, Ukoba UK, Ajayi OO (2011) X-ray diffractometer characterization of South Western Nigeria's Dolomite. The Pacific Journal of Science and Technology 12(2):520-522, http://www. akamaiuniversity.us/PJST12_2_520.pdf

Arauz LJ, Jozala AF, Mazzola PG, Penna TCV (2009) Nisin biotechnological production and application: a review. Trends Food Sci Tech 20:146-154. doi:10.1016/j.tifs.2009.01.056

Bae S, Shoda M (2004) Bacterial cellulose production by fed-batch fermentation in molasses medium. Biotechnol Prog 20:1366-1371. doi:10.1021/bp0498490

Baptista-Neto A, Gouveia A, Gouveia ER, Badino AC Jr, Hokka CO (2000) Phenomenological model of the clavulanic acid production process utilizing Streptomyces clavuligerus. Braz J Chem Eng 17:4 7. doi:10.1590/S0104-66322000000400043

Brown RMJR (2003) Cellulose structure and biosynthesis: what is in store for the 21 st century? J Polym Sci Part A: Polym Chem 42:487495. doi:10.1002/pola.10877

Cai Z, Kim J (2010) Bacterial cellulose/poly(ethylene glycol) composite: characterization and first evaluation of biocompatibility. Cellulose 17:83-91. doi:10.1007/s10570-009-9362-5

Carreira P, Mendes JAS, Trovatti E, Serafim LS, Freire CSR, Silvestre AJD, Neto CP (2011) Utilization of residues from agro-forest industries in the production of high value bacterial cellulose. 
Bioresour Technol 102:7354-7360. doi:10.1016/j.biortech.2011.04. 081

Castro C, Zuluaga R, Putaux JL, Caro G, Mondragon I, Gañán P (2011) Structural characterization of bacterial cellulose produced by Gluconacetobacter swingsii sp. from Colombian agroindustrial wastes. Carbohydr Polym 84:96-102. doi:10.1016/j.carbpol.2010. 10.072

Castro C, Zuluaga R, Cleenwerck I, Trcek J, De Vos P, Putaux JL, Gañán P (2013) Gluconacetobacter medellinensis sp. nov. cellulose- and non-cellulose producing acetic acid bacteria isolated from vinegar. Int J Syst Evol Micr 63(3):1119-1125. doi:10.1099/ijs. 0.043414-0

Donini IAN, De Salvi DTB, Fukumoto FK, Lustri WR, Barud HS, Marchetto R, Messaddeq Y, Ribeiro SJL (2010) Biosynthesis and recent advances in production of bacterial cellulose. Eclética Quím $35: 165-178$

Gomes FP, Silva HCSN, Trovatti E, Serafim LS, Duarte MF, Silvestre AJD, Pascoal Neto C, Freire CSR (2013) Production of bacterial cellulose by Gluconacetobacter sacchari using dry olive mill residue. Biomass Bioenergy 55:205-211. doi:10.1016/j.biombioe. 2013.02.004

Hong L, Wang YL, Jia SR, Huang Y, Gao C, Wan YZ (2006) Hydroxyapatite/bacterial cellulose composites synthesized via a biomimetic route. Mater Lett 60:1710-1713. doi:10.1016/j.matlet. 2005.12.004

Ishihara M, Matsunaga M, Hayashi N, Tisler V (2002) Utilization of Dxylose as carbon source for production of bacterial cellulose. Enzym Microb Technol 31:986-991. doi:10.1016/S0141-0229(02)00215-6

Joseph G, Rowe G, Margaritis A, Wan WK (2003) Effects of polyacrylamide-coacrylic acid on cellulose production by Acetobacter xylinum. J Chem Technol Biotechnol 78(9):964-970. doi:10.1002/jctb.869

Jung H, Lee OM, Jeong JH, Jeon YD, Park KH, Kim HS, An WG, Son HJ (2010) Production and characterization of cellulose by Acetobacter $s p$. V6 using a cost-effective molasses-corn steep liquor medium. Appl Biochem Biotechnol 162:486-497. doi:10. 1007/s12010-009-8759-9

Kennedy M, Krouse D (1999) Strategies for improving fermentation medium performance: a review. J Ind Microbiol Biotechnol 23: 456-475. doi:10.1038/sj.jim.2900755

Klemm D, Schumann D, Udhart U, Marsch S (2001) Bacterial synthesized cellulose - artificial blood vessels for microsurgery. Progr Polym Sci 26(9):1561-1603. doi:10.1016/S0079-6700(01)00021-1

Kongruang S (2008) Bacterial cellulose production by Acetobacter xylinum strains from agricultural waste products. Appl Biochem Biotechnol 148(1:3):245-256. doi:10.1007/s12010-007-8119-6

Kouda T, Yano H, Yoshinaga F (1997) Effect of agitator configuration on bacterial cellulose productivity in aerated and agitated culture. J Ferment Bioeng 83(4):371-376. doi:10.1016/S0922-338X(97) 80144-4

Koutinas AA, Sypsas V, Kandylis P, Michelis A, Bekatorou A, Kourkoutas Y, Kordulis C, Lycourghiotis A, Banat IM, Nigam P, Marchant R, Giannouli M, Yianoulis P (2012) Nano-tubular cellulose for bioprocess technology development. PLos ONE 7(4): e34350. doi:10.1371/journal.pone. 0034350

Kurosumi A, Sasaki C, Yamashita Y, Nakamura Y (2009) Utilization of various fruit juices as carbon source for production of bacterial cellulose by Acetobacter xylinum NBRC 13693. Carbohydr Polym 76:333-335. doi:10.1016/j.carbpol.2008.11.009

Li Y, Tian C, Tian H, Zhang J, He X, Ping W, Lei H (2012) Improvement of bacterial cellulose production by manipulating the metabolic pathways in which ethanol and sodium citrate involved. Appl Microbiol Biotechnol 96:1479-1487. doi:10.1007/s00253-012-4242-6

Lin WC, Lien CC, Yeh HJ, Yu CH, Hsu SH (2013) Bacterial cellulose and bacterial cellulose-chitosan membranes for wound dressing applications. Carbohydr Polym 94:603-611. doi:10.1016/j.carbpol. 2013.01.076
Masaoka S, Ohe T, Sakota N (1993) Production of cellulose from glucose by Acetobacter xylinum. J Ferment Bioeng 75:18-22. doi:10.1016/ 0922-338X(93)90171-4

Mikkelsen D, Flanagan BM, Dykes GA, Gidley MJ (2009) Influence of different carbon sources on bacterial cellulose production by Gluconacetobacter xylinus strain ATCC 53524. J Appl Microbiol 107(2):576-583. doi:10.1111/j.1365-2672.2009.04226.x

Mohite BV, Patil SV (2014) A novel biomaterial: bacterial cellulose and its new era applications. Biotechnol Appl Biochem 61(2):101-110. doi:10.1002/bab.1148

Moosavi-Nasab M, Yousefi M (2011) Biotechnological production of cellulose by Gluconacetobacter xylinus from agricultural waste. Iran J Biotech 9(2):94-101

Nakagaito AN, Nogi M, Yano H (2010) Displays from transparent films of natural nanofibers. MRS Bull 35(3):214-218. doi:10.1557/ mrs2010.654

Naritomi T, Kouda T, Yano H, Yoshinaga F (1998) Effect of ethanol on bacterial cellulose production from fructose in continuous culture. $\mathrm{J}$ Ferment Bioeng 85(6):598-603. doi:10.1016/S0922-338X(98) 80012-3

Panesar PS, Chavan Y, Chopra HK, Kennedy JF (2012) Production of microbial cellulose: response surface methodology approach. Carbohydr Polym 87:930-934. doi:10.1016/j.carbpol.2011.08.002

Park ST, Kim E, Kim YM (2006) Overproduction of cellulose in Acetobacter xylinum KCCM 10100 defective in GDPmannosyltransferase. J Microbiol Biotechnol 16(6):961-964

Phisalaphong M, Jatupaiboon N (2008) Biosynthesis and characterization of bacteria cellulose-chitosan film. Carbohydr Polym 74(3):482488. doi:10.1016/j.carbpol.2008.04.004

Pourramezan GZ, Roayaei AM, Qezelbash QR (2009) Optimization of culture conditions for bacterial cellulose production by Acetobacter sp. 4B-2. Biotechnology 8:150-154

Rani MU, Navin KR, Appaiah KAA (2011) Statistical optimization of medium composition for bacterial cellulose production by Gluconacetobacter hansenii UAC09 using coffee cherry husk extract-an agro-industry waste. J Microbiol Biotechnol 21:739

Rivas B, Moldes AB, Domínguez JM, Parajó JC (2004) Development of culture media containing spent yeast cells of Debaryomyces hansenii and corn steep liquor for lactic acid production with Lactobacillus rhamnosus. Int J Food Microbiol 97(1):93-98. doi: 10.1016/j.ijfoodmicro.2004.05.006

Rosales E, Couto SR, Sanromán MA (2005) Reutilization of food processing wastes for production of relevant metabolites: application to laccase production by Trametes hirsute. J Food Eng 66:419-423. doi:10.1016/j.jfoodeng.2004.04.010

Ruka D, Simon GP, Dean KM (2012) Altering the growth conditions of Gluconacetobacter xylinus to maximize the yield of bacterial cellulose. Carbohydr Polym 89(2):613-622. doi:10.1016/j.carbpol.2012. 03.059

Saibuatong OA, Phisalaphong M (2010) Novo aloe vera-bacterial cellulose composite film from biosynthesis. Carbohydr Polym 79(2): 455-460. doi:10.1016/j.carbpol.2009.08.039

Shah N, Ul-Islam M, Khattak WA, Park JK (2013) Overview of bacterial cellulose composites: a multipurpose advanced material. Carbohydr Polym 98:1585-1598. doi:10.1016/j.carbpol.2013.08.018

Sheykhnazari S, Tabarsa T, Ashori A, Shakeri A, Golalipour M (2011) Bacterial synthesized cellulose nanofibers; effects of growth times and culture mediums on the structural characteristics. Carbohydr Polym 86(3):1187-1191. doi:10.1016/j.carbpol.2011.06.011

Thiry M, Cingolani D (2002) Optimizing scale-up fermentation processes. Trends Biotechnol 20(3):103-105. doi:10.1007/s00253-0050003-0

Vandamme EJ, De Baets S, Vanbaelen A, Joris K, DeWulf P (1998) Improved production of bacterial cellulose and its application potential. Polym Degrad Stab 59(1-3):93-99. doi:10.1016/S01413910(97)00185-7 
Vazquez A, Foresti ML, Cerrutti P, Galvagno M (2013) Bacterial cellulose from simple and low cost production media by Gluconacetobacter xylinus. J Polym Environ 21:545-554. doi:10. 1007/s10924-012-0541-3

Verschuren PG, Cardona TD, Robert Nout MJ, De Gooijer KD, Van Den Heuvel JC (2000) Location and limitation of cellulose production by Acetobacter xylinum established from oxygen profiles. J Biosci Bioeng 89:414 419. doi:10.1016/S1389-1723(00)89089-1

Wu JM, Liu RH (2012) Thin stillage supplementation greatly enhances bacterial cellulose production by Gluconacetobacter xylinus.
Carbohydr Polym 90(1):116-121. doi:10.1016/j.carbpol.2012.05. 003

Yan Z, Chen S, Wang H, Wang B, Jiang J (2008) Biosynthesis of bacterial cellulose/multi-walled carbon nanotubes in agitated culture. Carbohydr Polym 74:659-665. doi:10.1016/j.carbpol. 2008.04.028

Zeng W, Small DP, Wan W (2011) Statistical optimization of culture conditions for bacterial cellulose production by Acetobacter xylinum BPR 2001 from maple syrup. Carbohydr Polym 85:506-513. doi: 10.1016/j.carbpol.2011.02.034 